\title{
Politics of Law Handling of Criminal Acts of Terrorism (Case Study In The District of Kudus)
}

\author{
Subkhan $^{1}$ and Widayati ${ }^{2}$
}

Abstract. Terrorism is a criminal act tremendous concern today's world, especially in Indonesia. Terrorism that occurred in Indonesia lately has associated ideological, historical and political as well as a dynamic part of the strategic environment at regional and global level. Terrorism is in fact an act which violates humanitarian and human rights as well as the proof that terror is the action of a very cruel and did not take into account, disregard and ignore the human values referred to in the second principle of Pancasila which became ideology Indonesian Nation humanity fair and civilized.

In general, the legal political handling of criminal acts of terrorism in Indonesia as a strategic step taken by Government Regulation No. 1 of 2002 Post-Event 1 Bali bombings to face a precarious state that fills a legal vacuum. That then pass the regulation established as Act No. 15 of 2003 on the Eradication of Terrorism does not diminish its value as a legal norm, but in the development of the substance of legislation are assessed tend to be repressive and still found the articles that have not been able to cover the dynamics of the spread of ideology radical who became the mother of terrorism, and prevent acts of terrorism itself.

Regulation alone is not appropriate presumably in combating terrorism, therefore we need other measures comprehensively, integral, planned and sustainable in the form of legal policy in order to cover the lack of normative law, by improving awareness and knowledge about the nationality and religious teachings properly, so that people can always be responsive and alert to the movement of radical groups that developed in the surrounding area.

Keywords: Politics of Law; Handling, Management of Terrorism Crime.

\section{Introduction}

Terrorism is a criminal act tremendous concern today's world, especially in Indonesia. Terrorism that occurred in Indonesia lately has associated ideological, historical and political as well as a dynamic part of the strategic environment in the global and regional level. Despite acts of terrorism that occurred in various regions in recent years is mostly carried out by the Indonesian people and only a few actors from the outside. Yet it can not be denied that terrorism today is a combination of domestic players with those who have a trans-national networks. ${ }^{3}$

In order to protect human values and human rights of citizens from acts of terrorism, the Government of Indonesia has established the Law Combating Criminal Acts of Terrorism, by preparing a Government Regulation in Lieu of Law (Government Regulation) No. 1 of 2002 on 4 April 2003 was passed into Act No. 15 of 2003 on the

\footnotetext{
${ }^{1}$ Student of Masters (S2) of Law Faculty of Law Unissula Semarang e-mail : bkhan.kds@gmail.com

${ }^{2}$ Lecturer of Faculty of Law UNISSULA Semarang

3 Muhammad A.S. Hikam, 2016, Deradikalisasi: Peran Masyarakat Sipil Indonesia Membendung Radikalisme, Jakarta: PT Kompas Media Nusantara, p. 33-34.
} 
Eradication of Terrorism. ${ }^{4}$ Manufacture of Government Regulation No. 1 of 2002 is the legal political steps are taken to fill the legal vacuum that occurred at that time. Long before the rise of incidents classified as a form of terrorism going on in the world, the international community and regional as well as various countries have attempted criminal policies is accompanied by systematic and comprehensive criminalization of the acts that are classified as terrorism. ${ }^{5}$

Any terror acts has obviously been harassing humanitarian values the dignity of the nation, and religious norms. Terror has shown in fact a human rights tragedy. Desdruktif impact caused escalation has or more touches multidimensional human life. Human identity, dignity as a civilized nation, and ideals can coexist with other nations in the noble mission of "universal peace" was defeated by terror. Because in so close this terror, terror finally shifted itself as "terrorism". That is, terrorism took part in the life of this nation to show other potentials of various types and kinds of crime, especially violent crime, organized crime, and crimes classified as extraordinary crime. ${ }^{6}$ Their own internal policy of the National Police that gives full authority over the criminal acts of terrorism prosecution centrally through the Detachment 88 AntiTerror, on the basis that this crime is a crime across the region, making regional units tend to be a support function. But the existence of these support functions became an important part because the extent of its competence in preventive action (cons radical) and post-action (deradical). One task of the unit area is served to fortify the society of the influence of radical ideology and host the return of the perpetrators of terrorism after serving his sentence, meaning that if not done deradicalised the potential to re-join the group is still very huge.

In various incidents of terrorism in Indonesia, it is known that the Kudus District least have accounted for three of its citizens in the list of terrorists who were killed in a shootout with Detachment 88 Anti-Terror Police Headquarters in Surakarta and Kebumen, accounted for three of its citizens who has radical homicidal preacher in Jepara, but it also never an option for some terrorists hiding place both within and outside the country and be a domicile of choice exs-five terrorist prisoners in many cases after serving his sentence. ${ }^{7}$

Based on the above description of the background of the authors are interested to write a paper entitled "Politics Of Law Handling Of Criminal Acts Of Terrorism Case Study In The District Of Kudus."

Based on the background outlined above, the authors formulate the problem to be studied in more detail, among other things: 1 ) How can the effectiveness of legislation criminal acts of terrorism in suppressing the spread of radical ideology and or prevent acts of terrorism?; 2) How legal policy solutions in order to minimize the spread of radicalism and or prevent acts of terrorism?

\footnotetext{
4 Romli Atmasasmita dan Tim, 2012, Analisis dan Evaluasi Peraturan Perundang- Undangan tentang Pemberantasan Tindak Pidana Terorisme (Undang-Undang Nomor 15 tahun 2003), Jakarta: The National Legal Development Agency of the Ministry of Justice and Human Rights, p. 73.

5 Muladi, 2002, "Hakekat Terorisme dan Beberapa Prinsip Pengaturan dalam Kriminalisasi," tulisan dalam Jurnal Kriminologi Indonesia FISIP UI, Vol II No. 03 December 2002, p. 1

6 Mardenis, 2011, Pemberantasan Terorisme: Politik Internasional dan Politik Hukum Nasional Indonesia, Jakarta: PT Raja Grafindo Persada, p. 120.

7 Kudus Police data.
} 


\section{Research methods}

This study uses the approach juridical sociological, namely legal research that emphasizes the steps of observation and analysis of empirical-qualitative, it is often called the "socio-legal research". ${ }^{8}$ Intended uses of the sociological juridical approach in this study is in the conduct of research, the author is more focused on primary data obtained from interviews and observations, to further assessed by secondary data obtained from library research related to the prevention of terrorism. Specifications of research used is descriptive analytical, which gives an overview on the prevention of terrorist acts based on the field data or empirical and secondary data were expressed by the respondents as well as the real behavior, which researched and studied as a whole.

\section{Result and Discussion}

\subsection{Effectiveness Of Legislation Criminal Acts Of Terrorism In Suppressing The Spread Of Radical Ideology And Or Prevent Acts Of Terrorism.}

Legislation criminal acts of terrorism which have been applied in Indonesia has not been able to suppress the spread of radical ideology which became the mother of terrorism and acts of terrorism or preventing the fullest. Some of the acts of terrorism in recent times still happen even though its intensity has been reduced, whether committed by the perpetrator or perpetrators of new and old back again. It shows that the enforcement of legal policy through legislation that is not optimally able to prevent acts of terrorism and to prevent former offenders return to their communities ${ }^{9}$.

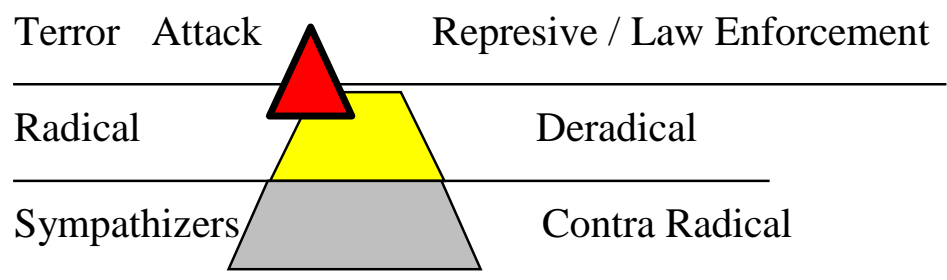

It happens because the rules of the existing legislation, namely Act No. 15 of 20013 still tend to be repressive that only focuses on law enforcement criminal acts of terrorism, while the spread of radicalism and creative opinions formed radical sympathizers have not been handled optimally. Besides law enforcement officers are often confronted with problems in the field, where the existing rules are sometimes not enough to reach a tort, it occurred along with the dynamics of an increasingly sophisticated form of terrorism. The rule can not accommodate due to terrorism-related acts that exist today or less guarantee the rule can be applied whether or not the perpetrators. The slow motion of the law itself makes it difficult to follow the social changes in the society. Thus it indirectly provides the opportunity for people to commit criminal acts of terrorism, because there is no action that can be imprisoned except under existing criminal provisions.

\footnotetext{
${ }^{8}$ Ronny Hanitijo Soemitro, 1982, Metodologi Penelitian Hukum, Ghalia Indonesia, Jakarta, p 17.

${ }^{9}$ Kudus Police data.
} 
Revised legislation by the Government together with the House of Representatives has resulted in Act No. 5 of 2018 is generally expected to cover the shortfall in the legislation earlier, among which appear chapters prevention in which there are passages of counter radical and deradical, but chapters are on the level of the concept and has not set things up that are applicable for direct government regulation is not published. The articles in this law is almost entirely set of action or act of terrorism, without wanting to know the background or cause of action or actions that happen, even in the general provisions of Act No. 5 of 2018 have never been defined on the term radicalism own.

Here it takes the political role of law in the form of legal policy. Criminal policy and criminal policy first proposed by Prof. Soedarto at the National Criminal Law Reform Symposium, August 28 to 30, 1980 in Semarang. Criminal politics in the broadest sense includes all the efforts made through legislation and the actions of the official body enforcing the fundamental norms embraced by the community.

That terrorism is always preceded by a radical understanding which is believed by the perpetrator. The shallowness of understanding of religion, social conflict and political and economic factors into one's potential is easier to accept propaganda and were driven into radical sympathizers, and to then be transformed into a sensible radical. From this radical berfaham then appeared terrorism.

In principle, the potential is not the cause, but put the most vulnerable position to more easily influenced and or receive radical understanding through the themes that exist, to then be influenced and directed to carry out acts of terror. Whereas the aforementioned potential will not be realized into Saxon radicals or terrorists when not meet some of the causes which; First, Heredity. Based on the data and the fact that many who become radicals or terrorists are the children of the radical leaders or the perpetrators of terrorism or having a family relationship. Second, the factors evoked the spirit of brotherhood through religious arguments are understood and applied incorrectly. Through this brotherhood spirit then someone will try to help others who are oppressed by concrete action in the form of retaliatory action, either directly or indirectly. Third, victims of propaganda ${ }^{10}$. Recruitment propaganda through Tabligh Akbar, public discussions, scientific and accompanied halaqoh video playback, as well as through print media, electronic media, online media, social media, articles and books that deliberately to influence opinions. Fourth, the victim recruitment through the stages of planting doctrine and pembai'atan then directed perform amaliyah in the form invite friends, fundraising, training (idad), terror (irhabiyah), kill (ightiyalat) and suicide bombings (istimata).

Seeing the causes mentioned above, the existence of laws that exist today can not be face to face or face to face to stem the activities that they cause someone to be sympathizers and has radicalism, because the law itself is in substance the chapters focus on actions or offenses which appear not on prevention.

\subsection{Minimize The Spread Of Radicalism And Or Prevent Acts Of Terrorism}

Regarding efforts to combat crime, GP Hoefnagels as quoted by Barda Nawawi Arif

${ }^{10}$ General Police Dr. H. Tito Karnavian, statement in Mabes Polri on $18^{\text {th }}$ July 2017. 
said that efforts to combat criminal acts can be reached at: ${ }^{11}$

- Criminal Law Application

- Without crime prevention (prevention without punishment)

- Affected public perceptions about crime convictions through mass media (Influencing views of society and punishment mass media).

The use of non penal facility focuses on preventive nature (prevention/ deterrence/control) before a criminal offense occurred. The emphasis of non penal facility was regarding the factors conducive cause of the crime, from the standpoint of criminal politics at the macro and global, non penal measures and a key strategic position in tackling the causes and conditions that give rise to crime. Non penal efforts, for example in the form of counter radical counter-narrative activity, counterpropaganda and counter-ideology and deradical in the form of national awarenessbuilding activities, religious and entrepreneurship.

Responding still much potential occurrence of terror attacks then President Joko Widodo ${ }^{12}$ decided to strengthen efforts to prevent acts of terrorism by revising Act No. 15 of 2003 on the Eradication of Terrorism. Pros and cons of the revision is associated with some of the crucial issues in the Terrorism Act itself, among others; related to the arrest, detention, prevention, position children as perpetrators of terrorism, tapping procedure, a sentence of death, revocation of citizenship, limit the military's involvement and strengthening victims' rights. ${ }^{13}$

At an iftar with the leaders of state agencies at the State Palace, Jakarta, May $18^{\text {th }}$, 2018, President Joko Widodo said that terrorism is an extraordinary crime, therefore, need extraordinary action as well as to combat it. So far, Indonesia focus on the fight against terrorism by means of repressive (hard power) in the form of law enforcement, to hunt down and dismantle the terrorist network to its roots. Confirmed by the President that the hard power approach is obviously very necessary but not enough, it's time to balance with soft power. ${ }^{14}$ Soft power of Jokowi is to promote preventive measures. These prevention efforts are not enough to de-radicalization process for inmates terrorism alone, but need to be coupled with educational institutions in Indonesia purge of radical understandings. The president also said that the mirror to the suicide bombings in Surabaya and Sidoarjo involving children and women, will be an important preventative measure. The event marked a radical ideology has entered the school and family environment. ${ }^{15}$

\footnotetext{
11 Barda Nawawi Arif, 1992, Upaya Non Penal Dalam Kebijakan Penanggulangan Kejahatan, Alumni, Bandung, p. 2.

12 Ir. Joko Widodo, Apa Kelemahan UU Terorisme Sehingga gagal Mencegah Aksi Bom?, merdeka.com 27 May 2017.

13 Institute for Criminal Justice Reform (ICJR), Thursday April $14^{\text {th }} 2016$, ICJR Serahkan Usulan DIM terhadap RUU Perubahan UU Pemberantasan Terorisme 2016 ke DPR RI, dalam http://icjr.or.id/icjrserahkan-usulan-dim-terhadap-ruu-perubahan-uu-pemberantasan-terorisme-2016-ke-dpr-ri/, accessed on Sunday 23 October 2016 at 17.10 WIB.

14 Transcript of Speech by the President at Iftar leaders of state agencies at the State Palace, Jakarta, May 18, 2018. The speech was also published in Tempo media which can be downloaded at https://nasional.tempo.co/read/1091407/jokowi-minta-diterapkan-cara-luar-biasa-melawan-terorisme, downloaded on August $2^{\text {nd }}, 2018$ at 20:00

15 Ibid.
} 
Taking into consideration the legal political shortcomings that have been taken in the form of Act No. 15 of 2003 and Act No. 52018 unpublished Regulation implementation, the handling of Terrorism at the regional level (district) has taken legal policy is local, but seen from the results of legal policy taken can already be seen the results, such as no cases of terrorism (especially in the district . Kudus), and the presence of some Exs Prisoners Terrorism has successfully returned to the bosom of the Republic of Indonesia with Pancasila.

Some legal policy taken at the regional level can generally be classified into two major ways:

- Prevention;

Precautionary or preventive measures is done to cover the lack of existing legislation related to the handling of terrorism. This is done by hope, when this is done constantly then the spread of radical ideology and terrorism will be resisted.

As for other forms of prevention activities (preventive) conducted among others; First, Doing formation of public opinion to remind you that the dangers of radicalism and terrorism still exists. The shape of these activities are done by putting up banners, distribute pamphlets, creating articles in online media and preached every counter radical activities via print and online media; Second, local regulations Arrange handling the deployment of radical ideology and the prevention of terrorism in the form of a Circular Letter and Letter of Appeal of Regents Kudus and the police chief, addressed to all elements of society related to the handling of the spread of radicalism and terrorism prevention; Third, Building a radical counter system by building synergy with the local government Kesbangpol Kudus Office for failure by utilizing the activities organized on behalf of coaching FORKOPIMDA, Kominda, FKDM, FKUB, BAKOR AJEL, CBOs and NGOs; Fourth, Building a radical counter system by building synergy with the Office of Education, Youth and Sports of the Kudus local government for the failure by utilizing the activities organized on behalf of the Student Community development, Community Youth and Community Youth Organization; Sixth, Building a radical counter system by building synergy with the Ministry of Religious Affairs Office of the Kudus local government for the failure by utilizing the activities organized on behalf of coaching Boarding School, Religious communities and community sermon Friday Madrasah and material nature of the influence of society membenteni radicalism and terrorism; Seventh, Building a radical counter system by building synergy with Universities for failure by utilizing the activities organized on behalf of student development.

- Post Repression;

Legal policy measures undertaken territorial unit (district) after this action is important as a form of de-radicalization good against Terrorist Inmates Exs and his family not to join again with radical or terrorist networks that previously followed an existing or new network. Forms of activities that have been carried out, among others; First, the emotional attachment to Exs Build Terrorist Inmates and their families with intensive communication and helps purposes that are related to the rights of citizens, for example in the manufacture of KTP, KK or SIM and facilitate 
other activities that have an impact on the establishment attitude to acknowledge the Homeland with Pancasila. Second,

Of the two things mentioned above, it can be seen that the organization of the material and the radical counter deradical that are applicable and not the concept is based on the argument of religion in order to compensate for the spread of radical efforts and the recruitment of terrorists that are based on religious proposition into something important. Explaining that Pancasila is appropriate Shari'a, Homeland already an Islamic state and the democratic system is not contrary to the teachings of Islam is done through the themes boosted with religious arguments. An understanding of some verses of the Qur'an, especially Surah Al Maidah 44, 45 and 47 and other passages for discussion a bit much to be more influential and to fortify the public from understanding the influence of radicals and the recruitment of terrorists, at the time of prevention activities (counter radical) and post-action (deradical) becomes very important. By understanding the argument of religion properly it will be able to counteract the spread of radical ideology and or prevents to commit acts of terrorism based on an understanding that religious proposition interpreted textural, wrong and misguided.

\section{Closing}

\subsection{Conclusion}

- Legal political handling of terrorism both through Government Regulation No. 1 of 2002 which was then set into Act No. 15 of 2003 and revised or amended into Act No. 5 of 2018 on the Eradication of Terrorism tends to still be repressive or law enforcement, and has not been able to cover it maximum cause namely the emergence of individual investigators and / radicals.

- Preventing terrorism can be done at the level of individual investigators and prevent/radicals. The principle of the prevention of terrorism to be part of the eradication of terrorism, because the terrorists only born of the individual radicals, so prevention is most effective when carried from upstream to downstream by involving all stakeholders in accordance with their respective roles. Kudus to be one territorial unit which has been taking steps that are local as part of legal policy that the results are quite able to minimize the spread of radical ideology and prevent acts of terrorism itself.

\subsection{Suggestion}

- Taking into consideration the existence of sub Invitation No. 5 of 2018 there still tends to be repressive, although in it have contained chapters that organize prevention is the concept, then it is worthwhile in the rules of procedure that government regulation is not created or endorsed included guidelines technically that is applied so that the existence of the rule of law will be completely in accordance with what is expected is able to prevent the criminal acts of terrorism inflicted.

- Prepare materials counter radical and deradical that are applicable and can be used as material or material face to face against the themes of the spread of the ideology 
of radical, so it will be able to shield society from the influence of the ideology of radical push towards terrorism without abandoning the efforts of law enforcement in the form of co-operation between institutions and related parties in the form of collaborative govermance as has been done in Kudus.

\section{Bibliography}

[1] Barda Nawawi Arif, 1992, Upaya Non Penal Dalam Kebijakan Penanggulangan Kejahatan, Alumni, Bandung.

[2] General Police Dr. H. Tito Karnavian, statement in Mabes Polri on $18^{\text {th }}$ July 2017.

[3] Institute for Criminal Justice Reform (ICJR), Thursday April $14^{\text {th }} 2016, I C J R$ Serahkan Usulan DIM terhadap RUU Perubahan UU Pemberantasan Terorisme 2016 ke DPR RI, dalam http://icjr.or.id/icjr-serahkan-usulan-dim-terhadap-ruuperubahan-uu-pemberantasan-terorisme-2016-ke-dpr-ri/, accessed on Sunday 23 October 2016 at 17.10 WIB.

[4] Ir. Joko Widodo, Apa Kelemahan UU Terorisme Sehingga gagal Mencegah Aksi Bom?, merdeka.com 27 May 2017.

[5] Mardenis, 2011, Pemberantasan Terorisme: Politik Internasional dan Politik Hukum Nasional Indonesia, Jakarta: PT Raja Grafindo Persada.

[6] Muhammad A.S. Hikam, 2016, Deradikalisasi: Peran Masyarakat Sipil Indonesia Membendung Radikalisme, Jakarta: PT Kompas Media Nusantara.

[7] Muladi, 2002, "Hakekat Terorisme dan Beberapa Prinsip Pengaturan dalam Kriminalisasi," tulisan dalam Jurnal Kriminologi Indonesia FISIP UI, Vol II No. 03 December 2002.

[8] Romli Atmasasmita dan Tim, 2012, Analisis dan Evaluasi Peraturan Perundang- Undangan tentang Pemberantasan Tindak Pidana Terorisme (Undang-Undang Nomor 15 tahun 2003), Jakarta: The National Legal Development Agency of the Ministry of Justice and Human Rights.

[9] Ronny Hanitijo Soemitro, 1982, Metodologi Penelitian Hukum, Ghalia Indonesia, Jakarta.

[10] Supriyadi Widodo, Erasmus A.T. Napitupulu, Ajeng Gandhini Kamliah, 2016, Catatan Kritis Atas RUU Pemberantasan Terorisme, Jakarta: Institute for Criminal Justice Reform.

[11] Transcript of Speech by the President at Iftar leaders of state agencies at the State Palace, Jakarta, May 18, 2018. The speech was also published in Tempo media which can be downloaded at https://nasional.tempo.co/read/1091407/jokowi-minta-diterapkan-cara-luarbiasa-melawan-terorisme, downloaded on August $2^{\text {nd }}, 2018$ at 20:00 